\title{
Cytotoxicity, Antiproliferative Effects, and Apoptosis Induction of Methanolic Extract of Cynometra cauliflora Linn. Whole Fruit on Human Promyelocytic Leukemia HL-60 Cells
}

\author{
T-Johari S. A. Tajudin, ${ }^{1}$ Nashriyah Mat, ${ }^{2}$ Abu Bakar Siti-Aishah, ${ }^{1}$ \\ A. Aziz M. Yusran, ${ }^{3}$ Afnani Alwi, ${ }^{1}$ and Abdul Manaf Ali $^{1}$ \\ ${ }^{1}$ Department of Biotechnology, Faculty of Agriculture and Biotechnology, Universiti Sultan Zainal Abidin, \\ Gang Badak Campus, 21300 Kuala Terengganu, Terengganu, Malaysia \\ ${ }^{2}$ Department of Agricultural Sciences, Faculty of Agriculture and Biotechnology, Universiti Sultan Zainal Abidin, \\ Gang Badak Campus, 21300 Kuala Terengganu, Terengganu, Malaysia \\ ${ }^{3}$ Department of Animal Science, Faculty of Agriculture and Biotechnology, Universiti Sultan Zainal Abidin, \\ Gang Badak Campus, 21300 Kuala Terengganu, Terengganu, Malaysia
}

Correspondence should be addressed to Abdul Manaf Ali, manaf@unisza.edu.my

Received 23 May 2012; Revised 25 August 2012; Accepted 10 September 2012

Academic Editor: Wagner Vilegas

Copyright (C 2012 T-Johari S. A. Tajudin et al. This is an open access article distributed under the Creative Commons Attribution License, which permits unrestricted use, distribution, and reproduction in any medium, provided the original work is properly cited.

\begin{abstract}
Methanolic extract of Cynometra cauliflora whole fruit was assayed for cytotoxicity against the human promyelocytic leukemia HL60 and the normal mouse fibroblast NIH/3T3 cell lines by using the MTT assay. The $\mathrm{CD}_{50}$ of the extract for 72 hours was $0.9 \mu \mathrm{g} / \mathrm{mL}$ whereas the value for the cytotoxic drug vincristine was $0.2 \mu \mathrm{g} / \mathrm{mL}$. The viability of the NIH/3T3 cells was at $80.0 \%$ when treated at $15.0 \mu \mathrm{g} / \mathrm{mL}$. The extract inhibited HL-60 cell proliferation with dose dependence. AO/PI staining of HL-60 cells treated with the extract revealed that majority of cells were in the apoptotic cell death mode. Flow cytometry analysis of HL-60 cells treated at CD 50 of the extract showed that the early apoptotic cells were 31.0, 26.3 and $19.9 \%$ at 24,48 , and 72 hours treatment, respectively. The percentage of late apoptotic cells was increased from 62.0 at 24 hours to 64.1 and 70.2 at 48 and 72 hours, respectively. Meanwhile, percent of necrotic cells were $4.9,6.6$, and 8.5 at 24,48 , and 72 hours, respectively. This study has shown that the methanolic extract of $C$. cauliflora whole fruit was cytotoxic towards HL-60 cells and induced the cells into apoptotic cell death mode, but less cytotoxic towards NIH/3T3 cells.
\end{abstract}

\section{Introduction}

Cynometra cauliflora (Leguminosae), a member of the bean family Fabaceae with vernacular name nam nam, is an indigenous plant of Malaysia that is widely distributed in South East Asia, Ceylon, and western and southern Peninsular of India [1]. This plant is a typical underutilized fruit tree that has the medicinal values in folk traditional medicine and cultivated as an ornamental plant in the village $[2,3]$. This evergreen and much-branched small tree or shrub can grow up to $15 \mathrm{~m}$ tall with flowers and fruits on its trunk. The fruits are kidney-shaped pod, greenish-yellow to brown in colour, with a rough and wrinkled surface. Unripe fruit tastes sour and the mature fruit is also cooked with sugar to make compote. It can also be consumed as fruit salad (ulam), pickled, or be used as a condiment based on pounded chili [1]. The fruit has a large seed that was reported to have low antioxidant capacity and moderately high in total phenolic content [3].

Ulam or traditional vegetables and medicinal plants of the Malaysian forest were reportedly rich in biological activities such as antimicrobial, cytotoxic, antiviral, anti-inflammation, antioxidant, antitumor promoting, and antidiabetic activities [4-11]. Several interesting natural product compounds were isolated from local medicinal plants such as 
damnacanthal from Morinda elliptica that was reported to have anti-HIV and immunomodulating activities [12-15], goniothalamin from Goniothalamus spp. that was cytotoxic towards leukemic cells and also induced apoptotic cell death $[16,17]$, as well as phytosterols from Coleus tuberosus, garcinia acid esters from Garcinia atroviridis, and girinimbine from Murraya koenigii that were reported to have antitumour promoting activities [18-20]. In this paper, we reported that the crude methanolic extract of $C$. cauliflora whole fruit has a very significant cytotoxicity towards promyelocytic leukemia HL-60 cells. However, the extract was less cytotoxic towards normal mouse fibroblast NIH/3T3 cells. The extract was found to inhibit the HL-60 cells proliferation and also induced apoptotic cell death mode.

\section{Materials and Methods}

2.1. Plant Identification and Documentation. The fruit of Cynometra cauliflora was collected from the district of Kuala Terengganu, Terengganu, Malaysia, and was identified by a botanist, Dr Nashriyah Mat, Department of Agricultural Science, Universiti Sultan Zainal Abidin, Malaysia. A voucher specimen was deposited at the herbarium of the Faculty of Agriculture and Biotechnology (HUDM 354114).

2.2. Sample Preparation. The whole fruits of C. cauliflora were dried in an oven at $40^{\circ} \mathrm{C}$ for 5 days and then soaked in methanol for another 3 days in the dark. The solvent was removed by using a rotary evaporator under reduced pressure at a temperature of $40^{\circ} \mathrm{C}$ and the residue was collected. A stock solution of the extract residue with concentration of $15.0 \mathrm{mg} / \mathrm{mL}(\mathrm{w} / \mathrm{v})$ was prepared in $100 \%$ dimethyl sulphoxide (DMSO) and then further diluted in RPMI-1640 free serum media to give a working stock concentration of $60.0 \mu \mathrm{g} / \mathrm{mL}$.

2.3. Cell Line. Human promyelocytic leukemia HL-60 and normal mouse fibroblast NIH/3T3 cell lines were purchased from ATCC (Manassas, VA, USA). Cells were grown in RPMI1640 media (Sigma, St. Louis, USA), supplemented with $10 \%$ foetal bovine serum (HyClone, USA) and antibiotics (100.0 units/mL penicillin and $100.0 \mu \mathrm{g} / \mathrm{mL}$ streptomycin) (PAA, Austria), and maintained in an incubator at $37^{\circ} \mathrm{C}$ with $5 \% \mathrm{CO}_{2}$ in a humidified atmosphere. HL-60 cells were subcultured every 2 or 3 days by splitting the culture $1: 1$ or $1: 2$ in the new flask with fresh growth medium. For adherent cells of $\mathrm{NIH} / 3 \mathrm{~T} 3$, semiconfluent cells were treated with trypsin-like enzyme with phenol red (Gibco, USA) for 5 minutes then the cells were resuspended in the medium with serum and transferred into 2 or 3 new flasks. Cell viability of above $95 \%$ was used throughout this study.

2.4. MTT Cytotoxicity Assay. The MTT assay was carried out in the 96-wells plate as described by Ali et al. [6]. Briefly, a volume of $50.0 \mu \mathrm{L}$ of complete growth medium was added into each well of 96-wells flat bottom microtiter plate (Nunclon, USA). The extract or vincristine sulphate solution (95.0-105.0\% purity by HPLC, Sigma, USA) at $60.0 \mu \mathrm{g} / \mathrm{mL}$ was aliquoted into wells in triplicate and serially diluted. A volume of $50.0 \mu \mathrm{L}$ of $1-2 \times 10^{5}$ cells $/ \mathrm{mL}$ HL-60 or NIH/3T3 cells were seeded into 96-wells flat microtiter plates and incubated for $72 \mathrm{~h}$ in $\mathrm{CO}_{2}$ incubator. After 72 hours incubation, a volume of $20.0 \mu \mathrm{L}$ of MTT solution $(5.0 \mathrm{mg} / \mathrm{mL})$ was added into each well and incubated for 4 hours. The culture medium was removed and $100.0 \mu \mathrm{L}$ of $100 \%$ DMSO solution were added to each well to solubilise the formazan formed [21]. The plates were read using the plate reader at $570 \mathrm{~nm}$ with reference at $630 \mathrm{~nm}$ wavelength (Infinite M200, Tecan, Switzerland). A dose response curve of the percentage of cell viable versus extract concentration was plotted.

2.5. Cell Proliferation Assay. Briefly in this assay, HL-60 cells at the concentration of $1 \times 10^{5}$ cells $/ \mathrm{mL}$ were incubated with extract at $\mathrm{CD}_{25}, \mathrm{CD}_{50}$, and $\mathrm{CD}_{75}$ values for 24,48 , and $72 \mathrm{~h}$ in 96-wells plates. The MTT assay was performed and the absorbance of each well was read at $570 \mathrm{~nm}$ with reference at $630 \mathrm{~nm}$ wavelength as mentioned above. The proliferation graph was established by plotting the optical density (OD) values versus time.

2.6. Acridine Orange and Propidium Iodide Staining (AO/PI). HL-60 cells were treated with the extract for 24 hours at $\mathrm{CD}_{50}$ concentration and $\mathrm{H}_{2} \mathrm{O}_{2}$ was used as a positive control. Cells without treatment were used as a negative control. Each of the treatment was done in triplicate. After 24 hours incubation, the cells were harvested into centrifuge tubes and pelleted down at $100 \mathrm{~g}$ for $10 \mathrm{~min}$. The cell pellets were washed with PBS by centrifuging the cells as mentioned above. Then the pellets were suspended in $50.0 \mu \mathrm{L}$ of acridine orange $(10.0 \mu \mathrm{g} / \mathrm{mL})$ and $50.0 \mu \mathrm{L}$ of propidium iodide $(10.0 \mu \mathrm{g} / \mathrm{mL})$ for $5 \mathrm{~min}$. A volume of $10.0 \mu \mathrm{L}$ of stained cells was pipetted onto glass slide and covered with a cover slip. The viable, apoptotic and necrotic cells were scored in a population of 100 cells as described by Ali et al. [22] by using the fluorescent microscope (Nikon TE2000-U, Nikon, Japan).

2.7. Flow Cytometry Analysis-Annexin V-FITC/PI. The HL60 cells were treated with extract at $C_{50}$ for $6,24,48$, and 72 hours. After incubation, cells were harvested into $5 \mathrm{~mL}$ centrifuge tubes and spun down at $300 \mathrm{~g}$ for $10 \mathrm{~min}$. Using cold PBS, the cells were washed trice and a volume of $100 \mu \mathrm{L}$ binding buffer (annexin V-FITC Apoptosis Detection Kit I, (Becton Dickenson)) was added into the tube. A volume of $1.25 \mu \mathrm{L}$ of Annexin V-FITC and $1.25 \mu \mathrm{L}$ PI solutions were added into the tube and incubated in the dark for $15 \mathrm{~min}$. Then a volume of $400 \mu \mathrm{L} 1 \mathrm{X}$ binding buffer was added to each tube and gently vortexed before analyzed by using a flow cytometer (FACSCalibur, (Becton Dickenson, USA)). About 10000 events were sorted accordingly into viable, early apoptotic, late apoptotic, and necrotic cells [23].

2.8. Statistical Analysis. Results were expressed as mean values with \pm standard deviation of the mean. All data were performed in triplicates and analyzed using the student's $t$ test or one-way ANOVA, where differences were considered significant at $P \leq 0.05$. 


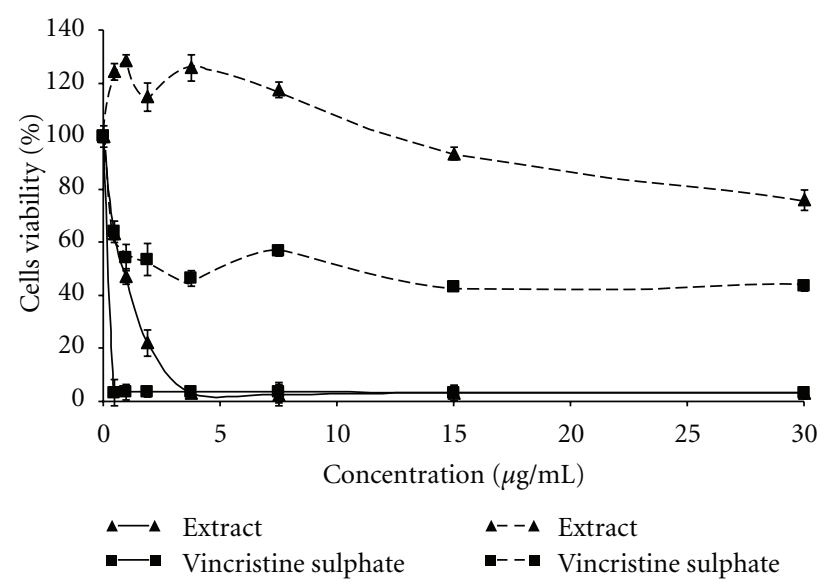

FIGURE 1: Effects of crude extract and vincristine sulphate on the viability of HL-60 cells ( $\boldsymbol{\Delta}-\boldsymbol{\Delta}$ extract; $\square-\square$ vincristine sulphate) and 3T3/NIH cells ( - - - $\mathbf{\Delta}$ extract; $\mathbf{\square}-\ldots$ vincristine sulphate) for $72 \mathrm{~h}$ incubation. Every point represents the mean of triplicate samples. Error bars represent the standard deviation.

\section{Results and Discussion}

Cytotoxicity effects of the extract towards HL-60 and NIH/ 3T3 cells were determined by measuring the cell viability using MTT assay after 72-hour treatment with the different concentrations of extract. The $\mathrm{CD}_{50}$ value was obtained from the plot between the concentrations of extract versus percent of cell viability. The value was used to describe the degree of cytotoxicity of the extract towards cell lines. Figure 1 shows that $\mathrm{CD}_{50}$ of the extract for the HL-60 cells was $0.9 \mu \mathrm{g} / \mathrm{mL}$. The graph also gave the concentration of the extract that reduced $25 \%$ of the cell population $\left(\mathrm{CD}_{25}\right)$ at $0.45 \mu \mathrm{g} / \mathrm{mL}$ and for $75 \%$ reduction $\left(\mathrm{CD}_{70}\right)$ the concentration was at $1.35 \mu \mathrm{g} / \mathrm{mL}$. However, the extract was less cytotoxic towards normal mouse fibroblast cell line NIH/3T3. The viability was not affected when treated with the extract at $15.0 \mu \mathrm{g} / \mathrm{mL}$ concentration but the viability of the cells was reduced to $80 \%$ when treated at $30.0 \mu \mathrm{g} / \mathrm{mL}(P<0.05)$. In this study, vincristine sulfate, a commercial drug for the treatment of leukemia and multiple myeloma was used as a positive cytotoxic control compound [24]. Vincristine is a vinca alkaloid from Catharanthus roseus (Madagascar periwinkle) and the compound is known to be a mitotic inhibitor [25]. The $\mathrm{CD}_{50}$ of vincristine for HL-60 cell was $0.2 \mu \mathrm{g} / \mathrm{mL}$ and $2.5 \mu \mathrm{g} / \mathrm{mL}$ for NIH/3T3 cells $(P<0.05)$. The viability of NIH/3T3 cells was drastically reduced to about $50 \%$ for the concentration of the extract below $2.0 \mu \mathrm{g} / \mathrm{mL}$ and remained at about $50 \%$ when the extract concentration was increased even at $30.0 \mu \mathrm{g} / \mathrm{mL}$ (Figure 1).

The extract was considered to possess a very strong cytotoxic activity towards HL-60 cells. The $\mathrm{CD}_{50}$ value of the extract was the same as the value of goniothalamin, a styrylpyrone derivative isolated from Goniothalamus species towards CEM-SS T-lymphoblastic leukemia cells which was reported by Ali et al. [22]. Extracts or compounds which demonstrated the $\mathrm{CD}_{50}$ value of $10-25 \mu \mathrm{g} / \mathrm{mL}$ were considered to be weak in cytotoxicity while compounds with the $\mathrm{CD}_{50}$ value of less than $5.0 \mu \mathrm{g} / \mathrm{mL}$ were considered very active. Those compounds or extracts that have intermediate value between 5.0 and $10.0 \mu \mathrm{g} / \mathrm{mL}$ of $\mathrm{CD}_{50}$ value were classified as moderately active [6].

The effects of extract at $\mathrm{CD}_{25}, \mathrm{CD}_{50}$, and $\mathrm{Cd}_{75}$ concentrations on the HL-60 cell proliferation was studied over a period of 72 hours. The absorbance at $570 \mathrm{~nm}$ wavelength after MTT assay was used as the indirect measurement number of viable cells. The cell proliferation rate was found to be significantly reduced with concentration dependence especially for the first 24 hours and further reduced at 48 and 72 hours (Figure 2). At $\mathrm{CD}_{25}$ concentration, the viable cells were decreased to $76.5 \%$ at 24 hours and further decreased to 64.3 and $54.5 \%$ at 48 and 72 hours, respectively $(P<0.05$ with respect to the untreated cells at the same time). At $\mathrm{CD}_{50}$ concentration, the viable cells were reduced to $46.9 \%$ at 24 hours and decreased to $34.5 \%$ at 72 hours. The viable cells of the HL-60 cells treated at $\mathrm{CD}_{75}$ were decreased to $15.67 \%$ at 24 hours and further decreased to 9.5 and $5.4 \%$ at 48 and 72 hours, respectively $(P<0.05$ with respect to the initial cell concentration). The proliferation rate of untreated HL-60 cell on the other hand was increased, as reflected in the OD values which were increased to $105.2,117.5$, and $129.3 \%$ at 24,48 , and 72 hours, respectively $(P<0.05$ with respect to the untreated cells of initial cell concentration).

3.1. Mode of Cell Death in HL-60 Cells. Acridine orange and propidium iodide dyes were used to differentiate viable, apoptotic, and necrotic cells under fluorescence microscope. Figure 3 shows the intact viable cells $(\mathrm{V})$, apoptotic $(A)$, and necrotic cells after the HL-60 cells were treated with the extract at $\mathrm{CD}_{50}$ concentration for 24 hours. Selective permeability property of intact plasma membrane of viable cells allowed the acridine orange to enter the cell and was impermeable to the propidium iodide. The nucleus of viable cells were stained with green-orange when observed under fluorescence microscope whereas the plasma membrane of necrotic cells was no longer intact which allowed propodium iodide to enter and make the cells appear red [22]. The integrity of plasma membrane of apoptotic cells is still intact but the morphology of the cells had changed with blebbing 


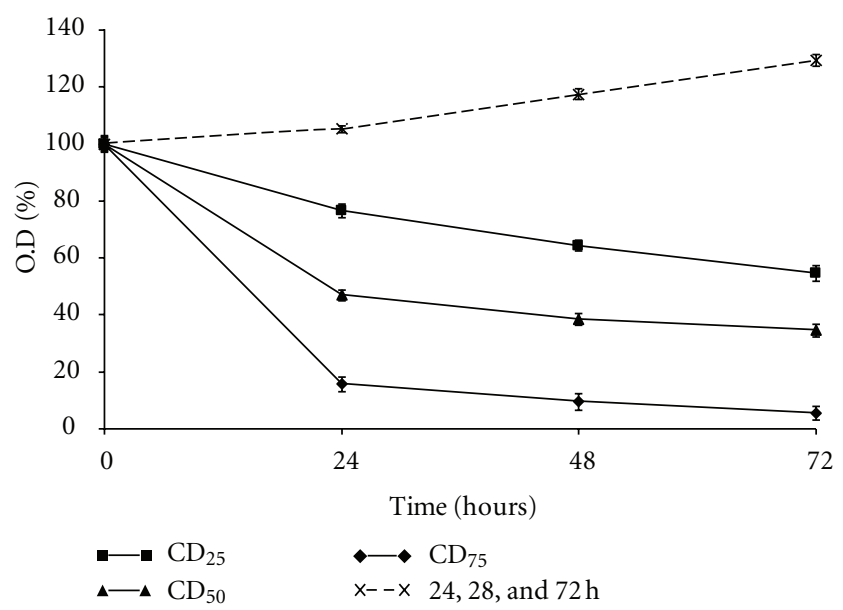

Figure 2: The growth curve of HL-60 cells after treatment with C. cauliflora extract at different cytotoxic doses $\left(\boldsymbol{\square}-\mathbf{\square} \mathrm{CD}_{25}, \boldsymbol{\Delta}-\mathbf{\Delta} \mathrm{CD}_{50}\right.$; $\longrightarrow \mathrm{CD}_{75}$ : untreated X- - -X) for 24, 48, and $72 \mathrm{~h}$. Every point represents the mean of triplicate samples. Error bars represent the standard deviation.

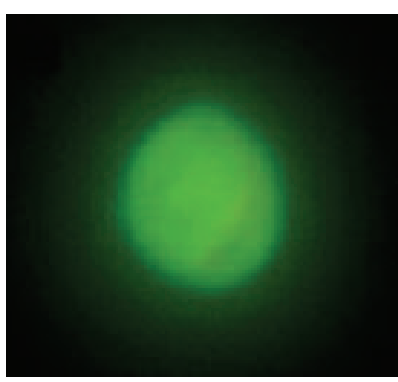

(a)

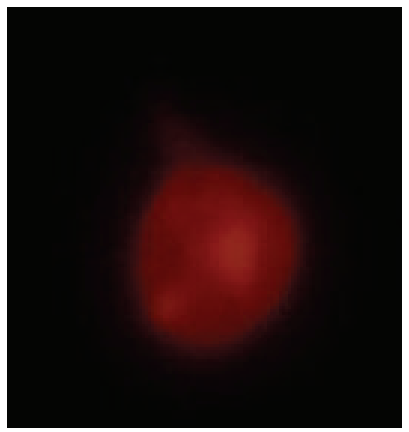

(c)

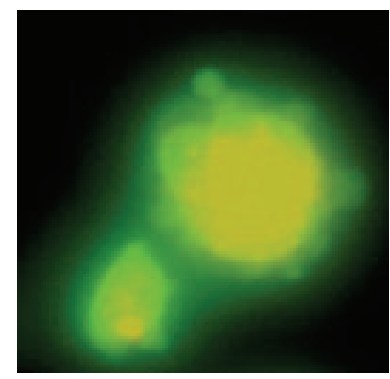

(b)

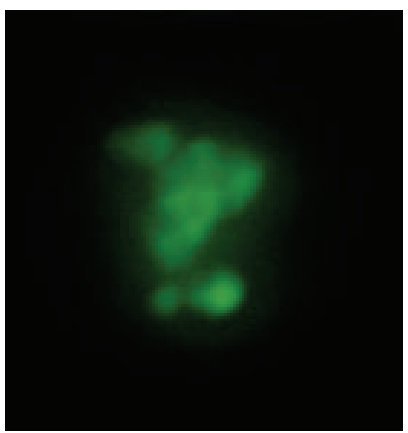

(d)

FIgURE 3: Morphological assessment of HL-60 cells treated with the extract of C. cauliflora for $24 \mathrm{~h}$ at $\mathrm{CD}_{50}$ after staining with acridine orange (AO) and propidium iodide (PI). (a) viable; (b) apoptosis; (c) necrosis; (d) apoptotic bodies (400x magnification).

plasma membrane and condensed nuclear chromatin [26$28]$.

The proportion of HL-60 cells in the early and late apoptotic and necrotic cell death modes was determined after the cells were treated with extract at $\mathrm{CD}_{50}$ dose for 24, 48, and 72 hours. The treated cells were stained with annexin V/PI and approximately 10,000 cells were analyzed by using the flow cytometry. The analyzed cells were grouped into four quadrants (Figure 4). The quadrant at the bottom on the left represents the viable cells which do not take both dyes. While cells at the early stage of apoptosis were stained with annexin $\mathrm{V}$ due to high affinity to the externalized phosphatidylserine on the surface of plasma membrane which represented in the second quadrant at the bottom on the right. Cells that were in the late apoptosis were stained with both dyes which represented in the third quadrant at top right and cells in necrosis were stained only with PI which represented in fourth quadrant at the top left [23]. The proportion of HL-60 cells in the early apoptosis was 31.0, 26.3, and 9.9\% after 24, 48 and 72 hours, respectively $(P<0.05$ respective to 


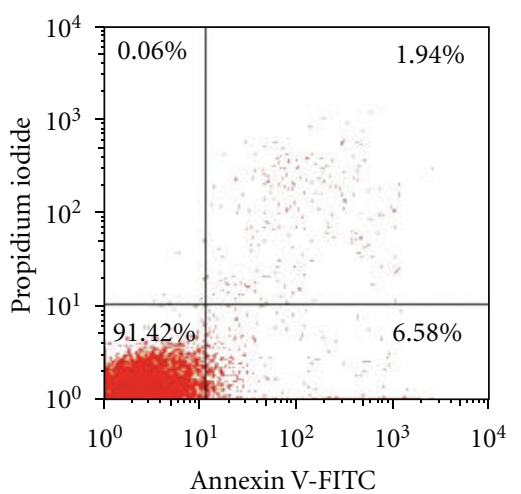

(A1)

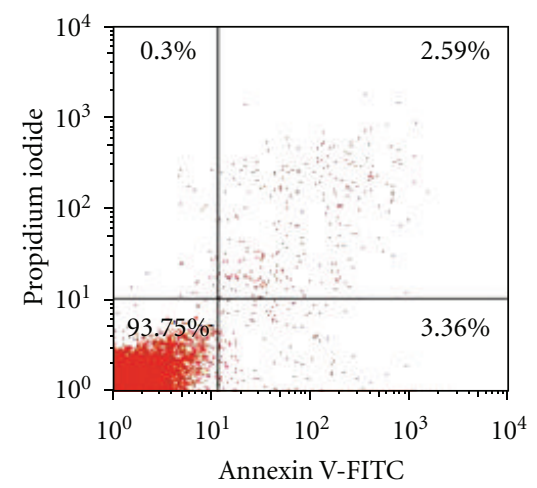

(A2)

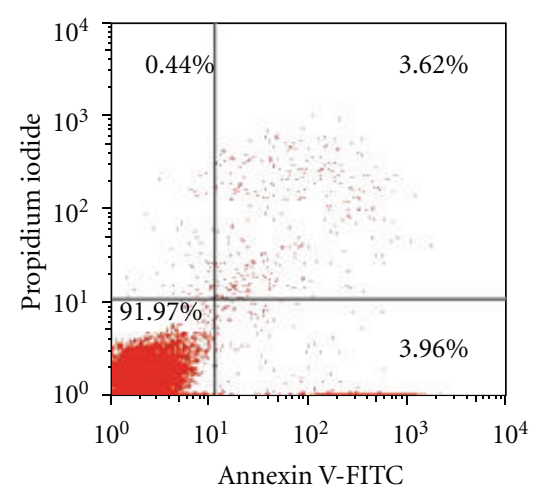

(A3)

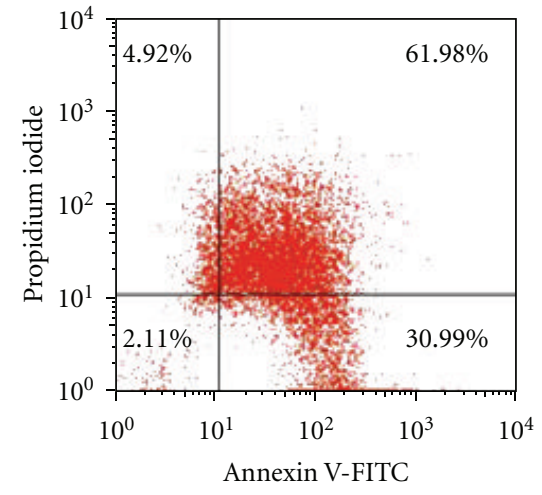

(B1)

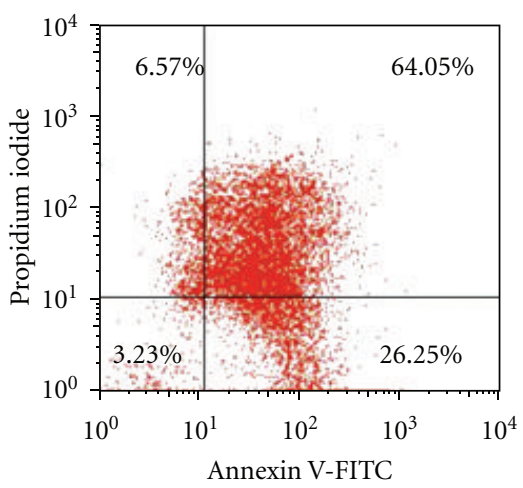

(B2)

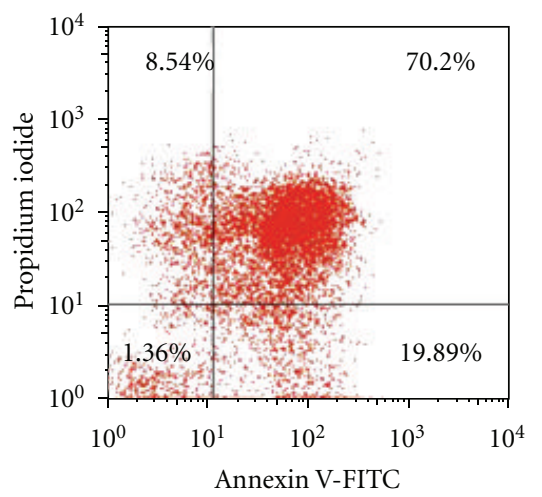

(B3)

Figure 4: Flow cytometry analysis of HL-60 cells untreated $(\mathrm{A} 1=24 \mathrm{~h}, \mathrm{~A} 2=48 \mathrm{~h}, \mathrm{~A} 3=72 \mathrm{~h})$ and treated with the extract at $\mathrm{CD}_{50}$ $(\mathrm{B} 1=24 \mathrm{~h}, \mathrm{~B} 2=48 \mathrm{~h}, \mathrm{~B} 3=72 \mathrm{~h})$ stained with annexin $\mathrm{V}$-FITC/propidium iodide (PI). Viable cells are in the lower left quadrant, early apoptotic cells are in the lower right quadrant, late apoptotic cells are in the upper right quadrant, and non-viable necrotic cells are in the upper left quadrant. Dot plots are a representative of 10,000 cells from a single replicate.

untreated cells at the same time). For cells that were in the late apoptosis, the proportion was increased from $62.0 \%$ at 24 hours to 64.1 and $70.2 \%$ at 48 and 72 hours, respectively. Meanwhile, the proportion of the cells in the necrosis was $4.9,6.6$, and $8.5 \%$ at 24,48 , and 72 hours, respectively $(P<0.05$ respective to untreated cells at the same time $)$. For the untreated HL-60 cells, the percentages of cells that undergo necrosis were below $1 \%$ at 72 hours incubation time (Figure 4).

\section{Conclusion}

This study had shown that methanolic extract of C. cauliflora whole fruit was very cytotoxic towards HL-60 cells and inhibits the cell proliferation. The extract induced the cells to die in majority through apoptotic cell death mode. However, the extract was found to be less cytotoxic towards $3 \mathrm{~T} 3 / \mathrm{NIH}$ cells. This observation is very important for future study on the isolation of cytotoxic compound(s) that are present in 
the extract. Furthermore, the in vivo antileukemic activity of the extract can be evaluated by using Balb/c leukemic mice induced with the WEHI-3B cells as reported by Alabsi et al. [29].

\section{Acknowledgment}

The authors would like to thank the Dean Faculty of Agriculture and Biotechnology, Universiti Sultan Zainal Abidin for his support of the project.

\section{References}

[1] I. H. Burkill, A Dictionary of the Economic Products of the Malay Peninsula, vol. 1, Ministry of Agriculture, Malaysia, Kuala Lumpur, 1966.

[2] M. Sedgley and J. A. Gardner, "International survey of underexploited tropical and subtropical perennials," Acta Horticulturae, vol. 250, pp. 140-177, 1989.

[3] E. H. K. Ikram, K. H. Eng, A. M. M. Jalil et al., "Antioxidant capacity and total phenolic content of Malaysian underutilized fruits," Journal of Food Composition and Analysis, vol. 22, no. 5, pp. 388-393, 2009.

[4] M. M. Mackeen, A. M. Ali, S. H. El-Sharkawy et al., "Antimicrobial and cytotoxic properties of some Malaysian traditional vegetables (Ulam)," International Journal of Pharmacognosy, vol. 35, no. 3, pp. 174-178, 1997.

[5] A. M. Ali, S. H. El-Sharkawy, J. A. Hamid, I. Nur-Hediani, and N. H. Lajis, "Antimicrobial activity of some Malaysian plants," Pertanika Journal of Tropical Agriculture Science, vol. 18, no. 1, pp. 49-52, 1995.

[6] A. M. Ali, M. M. Mackeen, and S. H. El-Sharkawy, "Antiviral and cytotoxic activities of some plants used in Malaysian indigenous medicine," Pertanika Journal of Tropical Agricultural Science, vol. 19, no. 2-3, pp. 129-136, 1996.

[7] L. Y. Mooi, A. M. Ali, A. B. Norhanom, K. M. Salleh, A. Murakami, and K. Koshimizu, "Anti-tumor promoting activity of some Malaysian traditional vegetables (ulam)," Natural Product Sciences, vol. 5, no. 1, pp. 33-38, 1999.

[8] M. Habsah, M. Amran, M. M. Mackeen et al., "Screening of Zingiberaceae extracts for antimicrobial and antioxidant activities," Journal of Ethnopharmacology, vol. 72, no. 3, pp. 403-410, 2000.

[9] A. Murakami, A. M. Ali, K. Mat-Salleh, K. Koshimizu, and H. Ohigashi, "Screening for the in vitro anti-tumor-promoting activities of edible plants from Malaysia," Bioscience, Biotechnology and Biochemistry, vol. 64, no. 1, pp. 9-16, 2000.

[10] M. Hamid, S. P. M. Bohari, M. S. Bastami, A. M. Ali, N. M. Mustapha, and K. Shari, "Evaluation of the insulinotrophic activity of Malaysian traditional plants extract," Journal of Biological Sciences, vol. 8, no. 1, pp. 201-204, 2008.

[11] R. Ahmad, A. M. Ali, D. A. Israf, N. H. Ismail, K. Shaari, and N. H. Lajis, "Antioxidant, radical-scavenging, anti-inflammatory, cytotoxic and antibacterial activities of methanolic extracts of some Hedyotis species," Life Sciences, vol. 76, no. 17, pp. 19531964, 2005.

[12] N. H. Ismail, A. M. Ali, N. Aimi, M. Kitajima, H. Takayama, and N. H. Lajis, "Anthraquinones from Morinda elliptica," Phytochemistry, vol. 45, no. 8, pp. 1723-1725, 1997.

[13] A. M. Ali, N. H. Ismail, M. M. Mackeen et al., "Antiviral, cyototoxic and antimicrobial activities of anthraquinones isolated from the roots of Morinda elliptica," Pharmaceutical Biology, vol. 38, no. 4, pp. 298-301, 2000.
[14] N. B. Alitheen, A. A. Manaf, S. K. Yeap, M. Shuhaimi, L. Nordin, and A. R. Mashitoh, "Immunomodulatory effects of damnacanthal isolated from roots of Morinda elliptica," Pharmaceutical Biology, vol. 48, no. 4, pp. 446-452, 2010.

[15] B. M. A. Noorjahan, A. M. Ali, S. K. Yeap et al., "Cytotoxicity and immunomodulatory effects of damnacanthal and nordamnacanthal Isolated from roots of Morinda elliptica," Journal of Agrobiotechnology, vol. 1, no. 1, pp. 29-42, 2010.

[16] A. M. Ali, M. M. Mackeen, M. Hamid et al., "Cytotoxicity and cell death induced by goniothalamin," Planta Medica, vol. 63, no. 1, pp. 81-83, 1997.

[17] S. H. Inayat-Hussain, A. B. Osman, L. B. Din et al., "Caspases3 and -7 are activated in goniothalamin-induced apoptosis in human Jurkat T-cells," FEBS Letters, vol. 456, no. 3, pp. 379383, 1999.

[18] L. Y. Mooi, N. A. Wahab, N. H. Lajis, and A. M. Ali, "Chemopreventive properties of phytosterols and maslinic acid extracted from Coleus tuberosus in inhibiting the expression of EBV early-antigen in Raji cells," Chemistry and Biodiversity, vol. 7, no. 5, pp. 1267-1275, 2010.

[19] Y. Y. Kok, L. Y. Mooi, K. Ahmad et al., "Anti-tumour promoting activity and antioxidant properties of Girinimbine isolated from the stem bark of Murraya koenigii S," Molecules, vol. 17, no. 4, pp. 4651-4660, 2012.

[20] M. M. Mackeen, L. Y. Mooi, M. Amran et al., "Noncytotoxic and antitumour-promoting activities of garcinia acid esters from Garcinia atroviridis Griff. ex T. Anders (Guttiferae)," Evidence-Based Complementary and Alternative Medicine, vol. 2012, Article ID 829814, 5 pages, 2012.

[21] T. Mosmann, "Rapid colorimetric assay for cellular growth and survival: application to proliferation and cytotoxicity assays," Journal of Immunological Methods, vol. 65, no. 1-2, pp. 55-63, 1983.

[22] A. M. Ali, N. T. Umar, S. M. Mohamed et al., "Induction of apoptosis in leukaemic cells by goniothalamin," Journal of Biochemistry, Molecular Biology and Biophysics, vol. 5, no. 3, pp. 227-235, 2001.

[23] S. H. Inayat-Hussain, A. B. Osman, L. B. Din, and N. Taniguchi, "Altholactone, a novel styryl-lactone induces apoptosis via oxidative stress in human HL-60 leukemia cells," Toxicology Letters, vol. 131, no. 3, pp. 153-159, 2002.

[24] I. S. Johnson, J. G. Armstrong, M. Gorman, and J. P. Burnett, "The vinca alkaloids: a new class of oncolytic agents," Cancer Research, vol. 23, pp. 1390-1427, 1963.

[25] G. Cardinali, G. Cardinali, and M. A. Enein, "Studies on the antimitotic activity of leuroscristine (vincristine)," Blood, vol. 21, no. 1, pp. 102-110, 1963.

[26] Z. Darzynkiewicz, G. Juan, X. Li, W. Gorczyca, T. Murakami, and F. Traganos, "Cytometry in cell necrobiology: analysis of apoptosis and accidental cell death (necrosis)," Cytometry, vol. 27, no. 1, pp. 1-20, 1997.

[27] J. C. Mills, N. L. Stone, and R. N. Pittman, "Extranuclear apoptosis: the role of the cytoplasm in the execution phase," Journal of Cell Biology, vol. 146, no. 4, pp. 703-707, 1999.

[28] S. M. Mohamed, A. M. Ali, M. Rahmani, C. Wiart, J. S. Dhaliwal, and K. Yusoff, "Apoptotic and necrotic cell death manifestations in leukemic cells treated with methylgerambullin a sulphone from Glycosmis calcicola (Rutaceae)," Journal of Biochemistry, Molecular Biology and Biophysics, vol. 4, no. 4, pp. 253-261, 2000.

[29] A. M. Alabsi, R. Ali, A. Ideris et al., "Anti-leukemic activity of newcastle disease virus strains AF2240 and V4-UPM in murine myelomonocytic leukemia in-vivo," Leukemia Research, vol. 36, no. 5, pp. 634-645, 2012. 


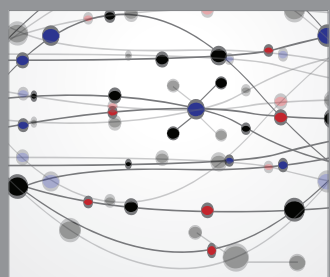

The Scientific World Journal
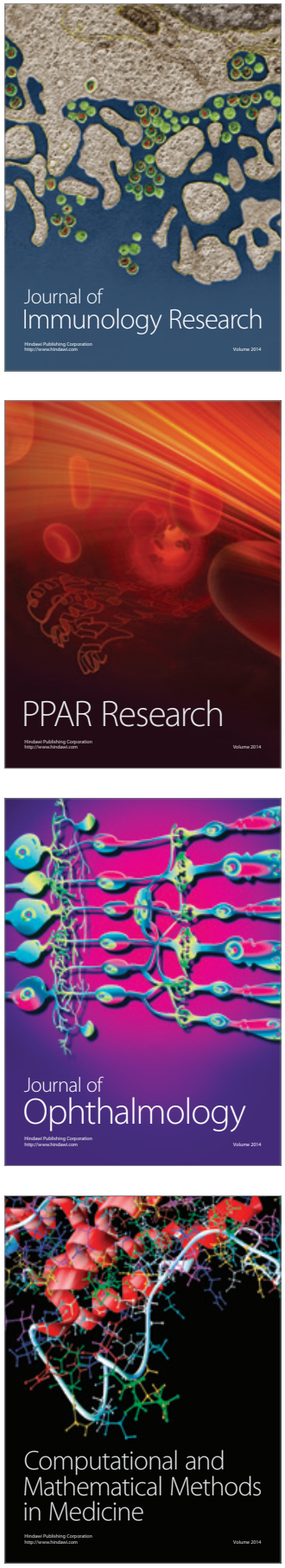

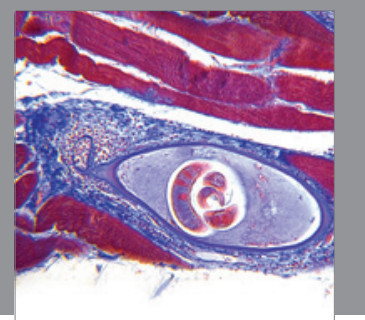

Gastroenterology

Research and Practice
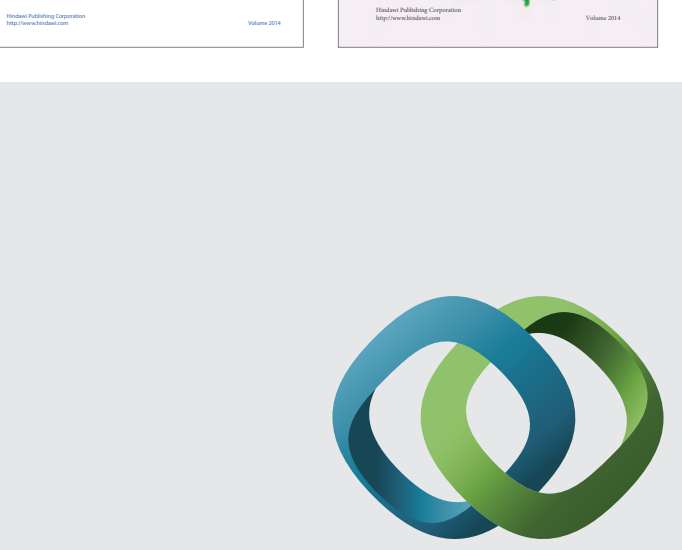

\section{Hindawi}

Submit your manuscripts at

http://www.hindawi.com
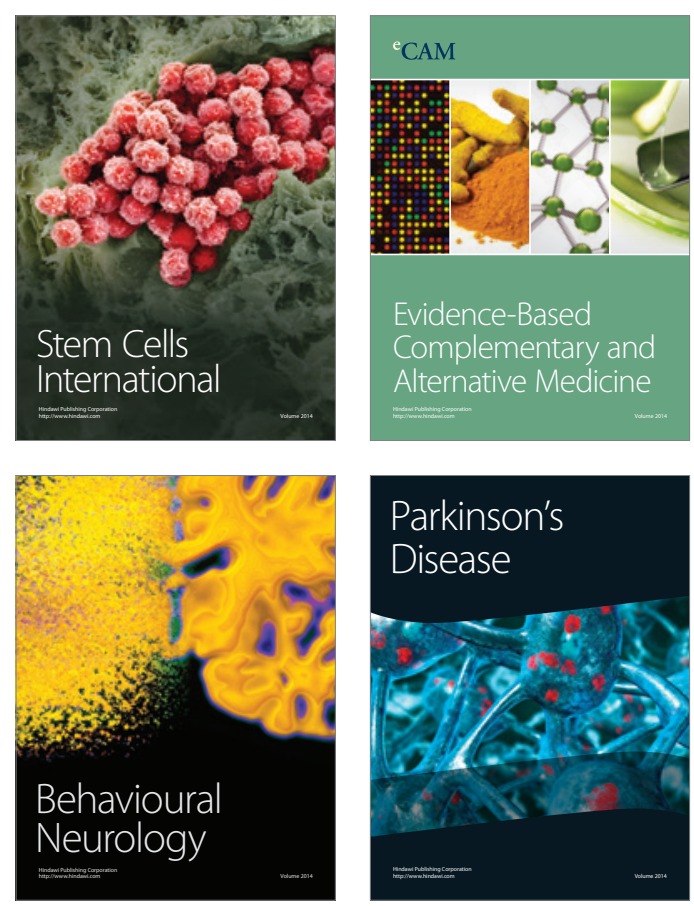

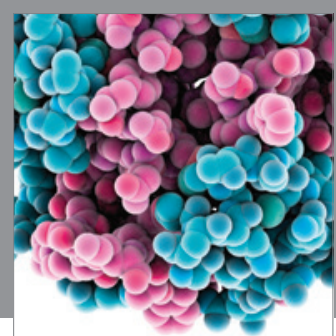

Journal of
Diabetes Research

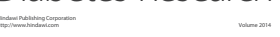

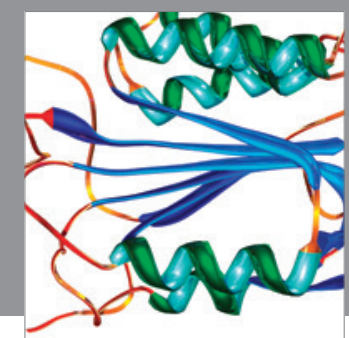

Disease Markers
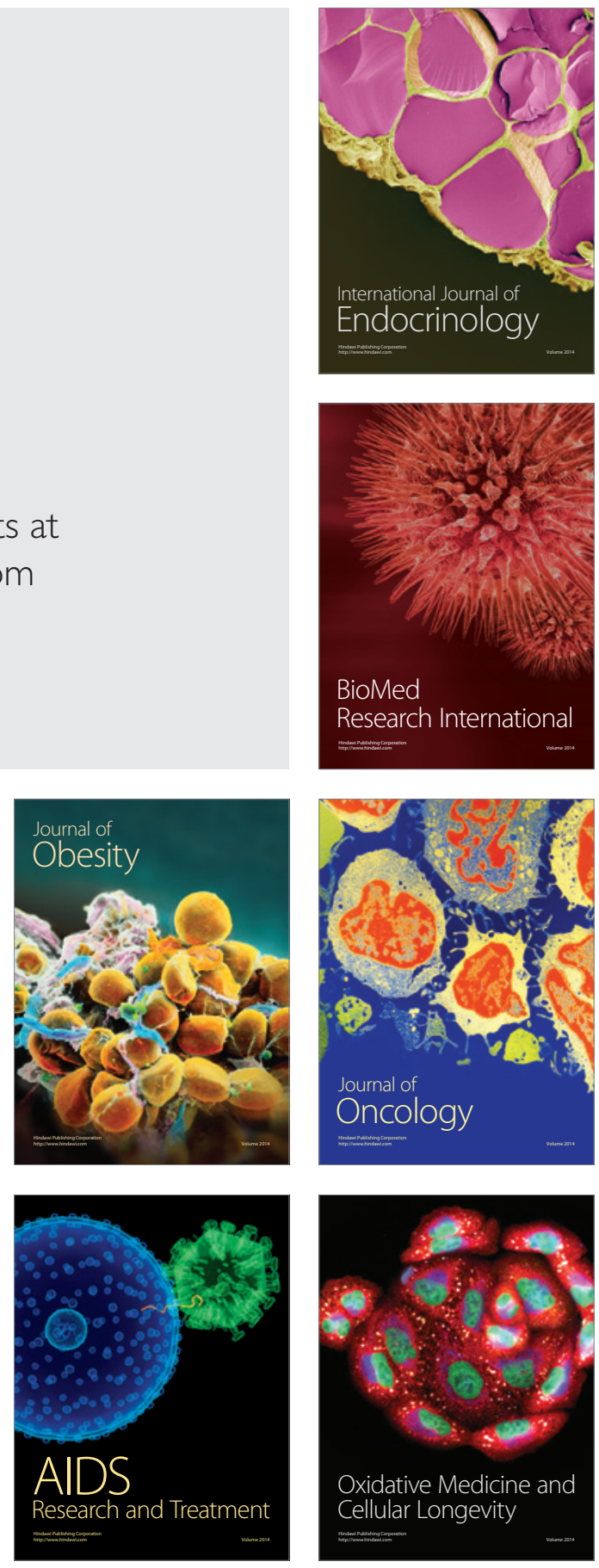